Article

\title{
Racial, Ethnic, or National Minority? Legal Discourses and Policy Frameworks on the Roma in Hungary and Beyond
}

\author{
Andras L. Pap \\ Department for the Study of Constitutionalism and the Rule of Law, Centre for Social Sciences Institute for Legal \\ Studies, Hungarian Academy of Sciences, 1014 Budapest, Hungary; E-Mail: papa@ceu.edu
}

Submitted: 28 January 2015 | In Revised Form: 28 March 2015 | Accepted: 8 April 2015 |

Published: 29 September 2015

\begin{abstract}
Inspired by recent Hungarian legislative developments that, in reference to the Roma minority, exchanged the term "ethnic minority" with "nationality", by providing a detailed case study of the development and morphology of policy measures and frameworks in Hungary, the article provides a general assessment of the relationship between policy instruments and terminology: that is, definitions and conceptualizations in international and domestic legal and policy documents for minority groups. The author argues that while terminology in itself is not a reliable signifier for policy frameworks, it may reveal contradictory group conceptualization and inconsistent policy-making. In regards to the Roma, the author claims that the inconsistent labelling as an ethnic, racial and national minority reflects the lack of consistent conceptualization of who the Roma are, and what should be done with them.
\end{abstract}

\section{Keywords}

ethnicity; Hungary; nation; Roma

\section{Issue}

This article is part of the special issue "Talking about Roma: Implications for Social Inclusion", edited by Dr. Eben Friedman (Independent Consultant and Senior Non-resident Research Associate, European Centre for Minority Issues, Germany).

(C) 2015 by the author; licensee Cogitatio (Lisbon, Portugal). This article is licensed under a Creative Commons Attribution 4.0 International License (CC BY).

\section{Introduction}

This question often arises concerning the phrase "Roma": does it refer to a social class, ${ }^{1}$ a race, an ethnicity, or a national minority? Inspired by recent Hungarian legislative developments that in reference to the Roma minority, exchanged the term "ethnic minority" with "Roma nationality", this paper starts by analyzing habitually used terms, definitions and conceptualizations in international and domestic legal and policy documents for minority groups.

I will first argue that the racial-ethnic-national mi-

\footnotetext{
1 Reflecting on Oscar Lewis' concept of the "culture of poverty" (1968), there has been a fierce debate among academics in Hungary on the applicability of the concept of "underclass" for Roma in Hungary and Eastern Europe (Ladányi, 2000; Ladányi \& Szelényi, 2000, 2001; Stewart, 2000, 2001).
}

nority terminology triad is unhelpful, and should be replaced by a more complex, functional set of categories, which better reflect socio-political realities, and the policy frameworks involved. I will also argue that group recognition is always politicized, and the form and substance of recognizing certain groups' legal and political aspirations will depend on the nature of their claims and its compatibility with the majority culture. I will claim that both in distinguishing between minority groups and in conceptualizing group membership, the question of external perception and the nature of the group-related claims will be of corollary importance. will also point to the intrinsic relationship between categorizing minority groups and conceptualizing and instrumentalizing membership criteria.

I will claim that when approaching the terminology issue from the point of legal and policy claims and frameworks, we see three clusters: minority rights fo- 
cus on the recognition and accommodation of cultural claims of both groups and individuals, as well as identity politics. Anti-discrimination legal and policy frameworks are individual rights oriented, and the third batch includes those various and diverse social inclusion measures, which "ethnicize" social policies or, endorsing multiculturalism, include the recognition of other forms of group-based, collective claims. I will argue that "national minorities", "nationalities", are adequate terminologies for the first cluster; "racial" and "ethnic" minorities for the second cluster, while the third approach institutionalizes a curious mix of all three. I will make a further concluding argument that terminology in itself is not a reliable signifier for the policy frameworks behind it, but contradictory and ambiguous group terminology may be a useful signal for the underlying inconsistent policies, which may be the product of decision makers' conceptual and policy inconsistencies. I will make the claim that the inconsistent labeling of the Roma as ethnic, racial and national minorities signals the fluidity and the indeterminate nature of conceptualizing and targeting the Roma-both on the European and national level. I will argue that this inconsistency in labeling reflects the lack of understanding (or at least a lack of consistently interpreting) who the Roma are, and what should be done with them.

In order to support my claims, the second part of the article will provide the case study of Hungary. In this part of the essay, I will be following the Hungarian legislators' terminology and use "nationality" in the sense of a group of people who share the same history, traditions, and language, and not as a reference to citizenship; meanwhile I acknowledge that this choice of terminology is unfortunate and somewhat confusing. As a further note on terminology, throughout the text, I have struggled with using the term "the Roma", faced both ethical and rhetorical dilemmas, as it (even unintentionally) may not only signal "othering", and an outsider position, but also hints that there is a unified, general definition for the denotation. This, going beyond the general lessons learned from critical race theory, in the case of "the Roma" is even more controversial, since group boundaries are extremely fluid, situational, and given that the concept of this transnational minority is a recent political construction, it differs vastly from other "ethnic" and "national minorities". Also, it is the very argument of this paper that the conceptualization of "the Roma" will be completely different when referencing rights holders for minority (cultural) rights, beneficiaries of social inclusion policies, and victims of discrimination. I also find it important to add that in this article the self-identification of Roma per se is not addressed, only the question of how particular categorizations of Roma are used in legal discourses. ${ }^{2}$

${ }^{2}$ On the Hungarian debate on who is Roma in Hungary, see

\section{Race, Ethnicity, and Nationality: Clusters for Conceptualizing Groups ${ }^{3}$}

In social sciences and law, the purpose of typologies and classification is to help us understand the internal logic and substance of concepts and institutions. Despite the fact that lawyers, legislators and drafters of international documents are well versed in creating definitions for concepts that are widely debated in social sciences and philosophy (consider for example the legal definition for poverty or disability), and notwithstanding the fact that the discourse on minority rights and adjacent policy frameworks are essentially lawbased, most international and domestic documents on minority rights, human rights and social inclusion actually refrain from defining several of their core concepts. As a result, we have to settle for vague descriptions of race, ethnicity, and nationality. In order to evaluate and contextualize the potential policy ramifications of different conceptualizations of "the Roma", the following pages will provide an overview of what race, ethnicity and nationality can mean in reference to this unique, transnational, multifaceted group with a diverse set of claims and a complex socio-political environment.

\subsection{Race and Ethnicity: Vague Categories, Inconsistent Application}

Race is a controversial category. In the social science literature, it is widely understood to be a social construct rather than a biological trait (in the biological sense, the entirety of humanity constitutes one single race) without a theoretically or politically uniform definition (see e.g. Tajfel (1981)). Race-based international and domestic legal instruments identify race with the apprehension of physical appearance, and put perception and external classifications in the center when prohibiting discrimination, or violence on racial grounds. In this, it is rarely distinguished from ethnicity, and the two terms are often used interchangeably by lawmakers (and drafters of international documents) and, most of all, judicial bodies. For example, under Article 1. of the 1965 International Convention on the Elimination of All Forms of Racial Discrimination, "the term 'racial discrimination' shall mean any distinction, exclusion, restriction or preference based on race, colour, descent, or national or ethnic origin...." Despite academic interest and insistence in differentiating between the two concepts, legal formulations seem to be unaware and unobservant of a potential difference between the two terms, and appear to be indifferent to it.

Feischmidt (2014), Havas, Kemény and Kertesi (1998), Kállai (2014), Ladányi and Szelényi (1998), Majtényi and Majtényi (2012), and Szalai (2003).

${ }^{3}$ For a more detailed analysis of issues raised in this chapter, see Pap (2015). 
One of the most widely cited legal definitions for race and ethnicity comes from the opinion of Lord Frazer of the House of Lords in the Mandla v Dowell Leeruling ([1983] 1 All ER 1062), which concerned whether Sikhs were a distinct racial group under the Race Relations Act: "For a group to constitute an ethnic [sic!ALP] group...it must,...regard itself, and be regarded by others, as a distinct community by virtue of certain characteristics. Some of these characteristics are essential; others are not essential but one or more of them will commonly be found and will help to distinguish the group from the surrounding community...(1) a long shared history, of which the group is conscious as distinguishing it from other groups, and the memory of which it keeps alive; (2) a cultural tradition of its own, including family and social customs and manners, often but not necessarily associated with religious observance...(3) either a common geographical origin, or descent from a small number of common ancestors; (4) a common language, not necessarily peculiar to the group; (5) a common literature peculiar to the group; (6) a common religion different from that of neighbouring groups or from the general community surrounding it; (7) being a minority or being an oppressed or a dominant group within a larger community...." Using these criteria, Frazer held that Sikhs "are a group defined by a reference to ethnic origins for the purpose of the [Race relations!-ALP] Act of 1976, although they are not biologically distinguishable from the other peoples living in the Punjab" (Human Rights Commission, 2004, p. 5).

This has also been the approach applied in cases involving members of Roma communities. In Koptova $v$. Slovakia ${ }^{4}$ and Lacko v. Slovakia ${ }^{5}$, the UN Committee on the Elimination of Racial Discrimination, the body in charge of supervising the aforementioned treaty, had no qualms about accepting complaints concerning the treatment of Roma, thus recognizing them as a racial group (see also Human Rights Commission, 2004, p. 10). The Grand Chamber of the European Court of Human Rights, spoke about racial discrimination against members of the Roma minority, when ruling against the Czech Republic in the segregation case of D.H. and Others v. the Czech Republic ${ }^{6}$ in January 2007. Most judicial bodies had no qualms about applying race and ethnicity as synonymous. In Chapman v. the United Kingdom $^{7}$ the Court accepted that gypsies constituted a distinct ethnic group in Britain by saying, "[T]he Applicant's occupation of her caravan is an integral part of her ethnic identity as a gypsy, reflecting the long tradition of that minority of following a travelling lifestyle". According to the Court in Sejdic and Finci v. Bos-

\footnotetext{
4 13/1998.

5 11/1998.

${ }^{6}$ Application No. 57325/00.

${ }^{7}$ Application No. 27238/95.
}

nia and Herzegovina: "Ethnicity and race are related concepts. Whereas the notion of race is rooted in the idea of biological classification of human beings into subspecies on the basis of morphological features such as skin colour or facial characteristics, ethnicity has its origin in the idea of societal groups marked in particular by common nationality, religious faith, shared language, or cultural and traditional origins and backgrounds. Discrimination on account of a person's ethnic origin is a form of racial discrimination." 8

While in 2004, the Irish Government, in the course of reporting to the United Nations Committee on the Elimination of Racial Discrimination, declared that Irish Travellers, "do not constitute a distinct group from the population as a whole in terms of race, colour, descent or national or ethnic origin", Romani and Gypsy (used interchangeably) and Irish Travellers have been held to be "ethnic" groups for the purpose of the Race Relations Act in the UK. In Commission for Racial Equality $v$ Dutton $^{9}$, a case dealing with the case of a London publican displaying a sign saying "No travellers" in his window, the Court of Appeals found that Romani were a minority with a long, shared history, a common geographical origin and a cultural tradition of their own. In $O^{\prime}$ Leary and others $v$ Allied Domecq and others ${ }^{10}$, a similar decision was reached with respect to Irish Travellers. In Hallam v. Cheltenham Borough Council ${ }^{11}$, the House of Lords also held that a local council's refusal to let public rooms to a Gypsy family for a wedding amounted to discrimination on racial grounds for the purposes of the Race Relations Act. Then again, when dealing with a number of Planning Act cases involving illegally encamped Gypsies, it said in Wrexham Borough Council v. Berry ${ }^{12}$ that one of the matters a court should take into account when considering an application for an injunction, was "the retention of his [the Gypsy Respondent's] ethnic identity" (at paragraph 41).

The Permanent Court of International Justice held in the Case of Greco-Bulgarian "Communities" (1930), that a minority community is: "a group of persons living in a given country or locality, having a race, religion, language and traditions of their own, and united by the identity of such race, religion, language and traditions in a sentiment of solidarity, with a view to preserving their traditions, maintaining their form of worship, securing the instruction and upbringing of their children in accordance with the spirit and traditions of their race and mutually assisting one another" (p. 26).

We can argue that if we want to grasp the substance of these definitions in the racial and ethnic mi-

\footnotetext{
8 Application nos. 27996/06 and 34836/06, p. 43.

9 [1989] 2 WLR 17, CA.

${ }^{10}$ Case No CL 950275-79, Central London County Court, Goldstein HHJ. See also McVeigh (2007).

11 [2001] UKHL 15.

12 [2003] UKHL 26, at paragraph 41.
} 
nority concept, there is one common element: the protection from maltreatment, that is, discrimination, hate crimes, hate speech, physical violence. Reflecting an anti-discrimination logic, the groups need to be defined by following the perpetrators' method: basing the definition of the group on the perception of either biologically determined characteristics or cultural attributes.

In a sense, however, ethnic minorities are multifaceted groups. While many of their claims are grounded in the anti-discrimination rhetoric employed by racial minorities, some "ethnically defined" groups, such as the Roma, may also have cultural claims (and protections) that national minorities would make. The international legal terminology habitually differentiates between the two groups on the grounds that ethnic minorities are different from national minorities in the sense that they do not have nation states as national homelands (Hannum, 2001). In this way, ethnic minorities are a sort of hybrid categorization, blending, and often mirroring, the claims made by racial and national groups.

The 1995 Council of Europe Framework Convention for the Protection of National Minorities (probably the most important international document on national minorities) also fails to provide a definition for its targets. ${ }^{13}$ (A relevant definition, also endorsed by the European Parliament's 2005 resolution ${ }^{14}$ on the protection of minorities and anti-discrimination policies in an enlarged Europe, is provided by the 1993 recommendation of the Parliamentary Assembly of the Council of Europe on an additional protocol on the rights of national minorities to the European Convention on $\mathrm{Hu}-$ man Rights: "'national minority' refers to a group of persons in a state who: reside on the territory of that state and are citizens thereof; maintain longstanding, firm and lasting ties with that state; display distinctive ethnic, cultural, religious or linguistic characteristics; are sufficiently representative, although smaller in number than the rest of the population of that state or of a region of that state; are motivated by a concern to preserve together that which constitutes their common identity, including their culture, their traditions, their religion or their language." ${ }^{15}$ )

When it comes to defining national minorities, I offer to settle for the definition that these are groups that, based on their claims for collective rights, bypass the anti-discriminatory logic and seek recognition of cultural and political rights, particularly autonomy or the toleration of various cultural practices that differ

\footnotetext{
${ }^{13}$ According to the Explanatory Report (1995), "It was decided to adopt a pragmatic approach, based on the recognition that at this stage, it is impossible to arrive at a definition capable of mustering general support of all Council of Europe member States" (para. 12). See also Kymlicka (2007).

14 2005/2008(INI).

${ }^{15}$ Recommendation 1201 (1993).
}

from the majority's, which often require formal exceptions from generally applicable norms and regulations. In this case, we are dealing with claims for preferential treatment. According to Will Kymlicka (2001), cultural minorities can be divided into two kinds, nations and ethnicities. The former is a historical community, more or less institutionally complete, occupying a given territory or homeland, sharing a distinct language or culture, the latter is a group with common cultural origins, but whose members do not constitute an institutionally complete society concentrated in one territory.

Concerning a special form of relationship between these clusters, we need to add the case when segregation is achieved by Roma parents being pressured to request specialized minority education, aimed originally at safeguarding Roma culture (Balogh, 2012a, $2012 b$ ). (This practice in not very common in Hungary but is well-documented.) The result is that Roma children are provided low-quality Roma folklore classes once a week, but are kept in separate, segregated classes, under inferior conditions. ${ }^{16}$

\subsection{Claims as a Basis for Categorization}

A useful way to help understand groups, and, I claim, the useful and meaningful way to conceptualize them, is to look at the claims they make. This should also serve as a helpful indicator for conceptualizing "the Roma". Based on the claims ethno-cultural groups in liberal democracies make, Will Kymlicka (2001) draws a five-way distinction among (i) national minorities, complete and functioning societies in historic national homelands which are either sub-state nations or indigenous peoples, (ii) immigrants, who do not want to engage in competing nation-building strategies, but want to negotiate the terms of integration (food, customs, holidays), (iii) voluntarily isolationist ethno-religious groups, which are unconcerned about marginalization, and seek exemption from certain laws, (iv) racial caste groups, and (v) Metics. (Kymlicka admits, however, that some groups like the Roma in Europe or African Americans are peculiar and atypical.). Minority rights claims, he concludes, may vary from immigrant multiculturalism to multination federalism, Metic inclusion, or religion-based exemptions from general laws. As Young (1997) sets out, "According to Kymlicka, justice for national minorities requires self-government rights of the national minority to govern their own affairs within their own territory, alongside and distinct from the larger society...Polyethnic rights, on the other hand,

\footnotetext{
${ }^{16}$ See the reports of the Parliamentary Commissioner for National and Ethnic Minority Rights (Kállai, 2011b, 2011c) and the report of the Parliamentary Commissioner for Fundamental Rights and of the Deputy Commissioner for the Protection of the Rights of Nationalities Living in Hungary (Szalayné Sándor \& Székely, 2014).
} 
give special recognition to cultural minorities in order to compensate for the disadvantages they would otherwise have in political participation and economic opportunity in the larger society. The objective of polyethnic rights is thus to promote the integration of ethnic minorities into the larger society, whereas selfgovernment rights of national minorities have a separatist tendency....The distinction between national minority and ethnic minority turns out to be a distinction between a[n immigrant-added by ALP] cultural group that wishes to and has the right to be a separate and distinct society, on the one hand, and a cultural minority that wishes to or is expected to integrate into a larger nation" (p. 49).

In line with Young's assessment, instead of a semantic analysis of the types of minorities, I propose a categorical distinction for minorities based on the aim of the particular protection mechanism sought. Instead of an empty typology, I call for a more complex set of criteria for distinguishing between minority groups, taking into consideration at least the origin of the group; the basis for group-formation; and the aspirations, needs, and demands of the group towards the majority. Let us not forget: rights protecting minorities may be dignity-based identity-claims; equality-based (synchronic or diachronic) justice claims; or even reciprocal diaspora claims. ${ }^{17}$

Protective measures for racial, ethnic, or national minorities may target a number of different things, such as: ${ }^{18}$ socio-economic equality, de facto freedom of religion, the protection of potential pogrom victims and the prevention of brutal ethnic conflicts, decreasing cultural conflicts between majority and genuine minority or immigrant groups, combating racial segregation or apartheid, or race-based affirmative measures of compensatory, remedial, or transitional justice. In line with this, laws protecting minorities may take several forms, ranging from affirmative action and social protection measures to declarations of religious and political freedom to setting forth cultural or political autonomy, or controlling political extremists. The contextdependent meaning of minority-protection may also refer to a widely diverse set of policies such as: equal protection (non-discrimination); participatory identity politics (the political participation of identity-based groups in political decision-making); cultural identity politics (the recognition of identity-based groups in cultural decision-making by the state); the protection of historically rooted identity-based sensitivity (the criminalization of hate-speech, holocaust-denial, etc.); affirmative action; special constitutional constructions

\footnotetext{
17 In certain ethno-political situations (in Hungary, for example), the approach to ethnic and national minority rights is defined by reference to ethnic kin's Diaspora-rights (in the neighboring states). See e.g. Pap (2006).

18 See e.g. Sajó (1993) or Bragyova (1994).
}

form-fitted for the needs of indigenous populations; policies recognizing claims which mirror the state's ethnic kin's Diaspora claims abroad; right to traditional, pre-colonization life; or simply measures designed to maintain international security.

\subsection{Recognition and Accommodation: The Political Sine Qua Non}

The political element in the success of certain groups' recognition as minorities can best be demonstrated with the dynamic interpretation of the scope of the Council of Europe Framework Convention for the Protection of National Minorities. For example, at the time of ratification, the German minority in South Jutland was identified as the only recognized national minority subject to the Framework Convention in Denmark. In 2000, the Advisory Committee urged the Danish government to reconsider the scope of application of the Framework Convention, in order to possibly include Faroese, Greenlanders and the Roma (Council of Europe, 2000).

It can be seen that the reception of groups' claims for protection and recognition, and institutionalizing these through the inclusion in the privileged club of minorities will depend on instances such as how compatible these claims are with the majority culture, how long is the group's common history with the majority, or whether there are historical or contemporary political sensitivities involved.

Bans on visible and politically loaded expressions of Islamic religion, such as women wearing headscarves, have, on the one hand, been repeatedly upheld by various judicial organs including the European Court of Human Rights (e.g. in Leyla Şahin v. Turkey; ${ }^{19}$ Dahlab v. Switzerland ${ }^{20}$ ). In Central-Eastern Europe, headscarves worn by Roma women in traditional communities trigger no public response-even though the anti-Romani racist rhetoric (in some ways analogously to Western European anti-Muslim political actors) envisions the Roma as agents of a cultural, or a demographic takeover and a security threat. Also, in the UK, in similar cases involving turbans worn by Sikhs, legislative and judicial tolerance includes exemptions from wearing a helmet even while riding a motorbike or working on a construction site. The reason lies within the perception of Sikhs as a "harmless" group in the UK, with no apparent or manifest social, cultural, or political conflicts with the majority society.

As demonstrated above, group recognition is always political, and the form and substance of recognizing a certain group's legal and political aspirations will depend on the nature of their claims and on how compatible those may be with the majority culture. Thus,

\footnotetext{
${ }^{19}$ Application no. 44774/98.

${ }^{20}$ Application no. 42393/98.
} 
the length of historic coexistence or even the basis for group-formation will be critical elements in this process. In these debates concerning the Sikhs in the UK, German citizens of Turkish descent, Maghrebi immigrants in France, or the Roma in different European countries, it is irrelevant whether they are referred to as racial, and national or ethnic minorities. The pertinent questions, rather, relate to what legal instruments can be called for in advocacy and along which lines are policies drafted. A useful inquiry is not semantic, but one focusing on the morphology of claims and the socio-legal climate. The very idea of group rights includes adjusting society's perception of equality by including certain groups as eligible claimants for such treatment. Even if, in theory, the existence of a minority should not depend on the State's decision, in practice this process of broadening of the agents of ethno-cultural justice and equality will always include a political decision and a value judgment. The process of recognizing minorities as minorities, as groups worthy of sui generis recognition (that other groups do not have), is highly politicized.

\subsection{Means to Ends: Concepts of Justice and Social Policy}

These questions, therefore cannot be separated from discussions concerning what concept of social justice and equality are decision makers endorsing in regard to the given community. As McCrudden (2005) points out, there are at least four different meanings of equality, and what may be suitable in one context, may not be in another. What he calls the "individual justice model" focuses on merit, efficiency and achievement and aims to reduce discrimination. Second, the "group justice model" concentrates on outcomes and the improvement of the relative positions of particular groups, with redistribution and economic empowerment at its core. Equality as the recognition of diverse identities is yet another dimension, since the failure to accord diversity is a form of oppression and inequality itself; and finally, the fourth conception of equality includes social dialogue and representation, the meaningful articulation of group priorities and perspectives (McCrudden, 2005). Each of these conceptions of equality also has a different concept at its core, corresponding respectively to: direct discrimination; indirect discrimination, group-level marginalization and oppression; cultural and linguistic rights; and participation in political and public policy decisions is in the center.

As mentioned above, a useful set of terms therefore should center around the substance of legal and policy claims and frameworks. Under this approach there are three clusters: minority rights have the recognition and accommodation of cultural claims of both groups and individuals, as well as identity politics in focus. The second array of legal and policy frame- works is individual rights oriented, and has antidiscrimination in focus. The term should be understood in the broad sense, including protection from hate crimes or even hate speech, and several other related individual-based human rights claims. The third batch includes those various and diverse social inclusion measures, which "ethnicize" social policies or, endorsing multiculturalism, include the recognition of other forms of group-based, collective claims. "National minorities", "nationalities", are adequate terminologies for the first, "racial" and "ethnic" minorities for the second cluster, while the third approach institutionalizes a curious mix of all three.

While acknowledging that according to Tajfel (1981) both "ethnicity" and "nationality" are group-like social constructs (and imagined cultural communities, even if conceptualized and essentialized as biologically determined), and "race" functions as a category created by essentialist external perceptions and criteria, this does not mean that an ethno-national vs. racial binary would be a useful simplification. Also, while arguably external perceptions and classifications are corollary to defining and differentiating between these approaches, a national vs. ethno-racial binary is similarly reductionist. My point is that the recognition of ethno-cultural claims and policies for enhancing certain groups' capabilities for participating in cultural and public life, and the preservation of their identities, have to be differentiated from measures providing equal treatment, or setting forth group-conscious social policies. Due to the uniquely complex situation of the Roma, what we see in Roma policies is the chaotic application of all of the above.

\subsection{Notes on Operationalization}

The operationalization of policies and concepts is a crucial issue. Ethno-national identity can be defined in several ways, all of which is applied in different Romarelated policies: through self-identification; by other members or elected, appointed representatives of the group (leaving aside legitimacy-, or ontological questions regarding the authenticity or genuineness of these actors); classification by outsiders, through the perception of the majority; or by outsiders but using "objective" criteria, such as names, residence, etc. As noted earlier, for anti-discrimination measures, subjective elements for identification with the protected group are irrelevant, and external perceptions serve as the basis for classification. Policies implementing this anti-discrimination principle may rely on a number of markers: skin color, citizenship, place of birth, country of origin, language (mother tongue, language used), name, color, customs (like diet or clothing), religion, parents' origin, or even eating habits (Simon, 2007). Defining membership criteria comes up in a completely different way when group formation is based on claims for different kinds of preferences and privileges. In this 
case, subjective identification with the group is an essential requirement, but the legal frameworks may establish a set of objective criteria that needs to be met besides. In the context of drafting affirmative action and ethnicity-based social inclusion policies, external perception, self-declaration, and anonymized data collection may be varied and combined. A special form of opting in to groups concerns mixed partnerships or marriages, where protections are extended to victims of discrimination by association.

When it comes to choosing legal or policy means to identify community membership, solutions should be tailored to match the policy frameworks. Thus, for hate crimes and discrimination, the perception of the majority and the perpetrators should be taken into consideration; in political representation, the perception of the minority community should matter; and in preferential treatment (remedial measures and affirmative action), self- identification along with community identification or endorsement should be key.

Policy makers may even find that attempts to misuse the system will inevitably occur. Thus, "explicit but not exclusive targeting", currently a dominant approach in the context of the European Union's Roma inclusion policies is a meeting-point between colorblind measures preferred by old Member States, and group-tailored "Roma policies" applied in CentralEastern Europe. According to Principle no. 2 of the Vademecum by the European Commission (2010), "This approach implies focusing on Roma people as a target group without excluding others who live under similar socio-economic conditions. Policies and projects should be geared towards 'vulnerable groups', 'groups at the margins of the labour market', 'disadvantaged groups', or 'groups living in deprived areas', etc. with a clear mention that these groups include the Roma. This approach is particularly relevant for policies or projects taking place in areas populated by the Roma together with other ethnic minorities or marginalized members of society".

\subsection{Inconsistent Terminology, Inconsistent Conceptualization and Policy Framing}

It has been shown that terminology in itself is not a reliable indicator for policy frameworks. On the other hand, contradictory and ambiguous group terminology may be a useful signal for the underlying inconsistent, confused and confusing policies, which may be the product of decision makers failing to take sides in broader debates concerning the multicultural or multiethnic nature of the states, or avoiding a straight forward commitment towards directly targeting minority groups to address inequality, or insisting on privileging individuals over groups (and favoring hybridity over boundaries, signing up for post-ethnicity, etc.) (Kaufman, 2014).
It is not too far-fetched a claim to make that the inconsistent terminology for the Roma as ethnic, racial and national minorities signals the fluidity and the indeterminate nature of conceptualizing and targetingboth on the European and national level. In order to support my claim, contextualized by recent Hungarian legislation that changed the label for the Roma from an "ethnic minority" to a "nationality", the following chapter provides an overview of how the Hungarian legislator and the European Union approached the Roma question in Hungary.

\section{Roma in the Pharisaic Hungarian Multiculturalist Model}

\subsection{The Roma in Hungary}

Debates and theories applied to multiculturalism in an immigration context need to be adjusted accordingly when talking about Hungary. In order to properly contextualize the Hungarian case, the following facts need to be stated concerning the Roma population. In the 2011 census, $6.5 \%$ of the population declared that they belong to one of the minority groups. According to the Council of Europe, the cultural rights and situation of the new minorities (immigrants) is a marginal issue; immigration figures are very low, and the overwhelming majority of immigrants are ethnic Hungarians from a neighboring state, who do not constitute a cultural minority. With an overall population of about 10 million, the immigration authorities recorded 213,000 foreigners living legally in Hungary in 2012 (Council of Europe \& ERICarts, 2015).

According to the Council of Europe (2010), 7.05\% of the total Roma population lives in Hungary. Roma constitute the largest minority group in the country. In the 2011 population census about $3.2 \%$ of the population, 308,957, were identified as Roma (Central Statistical Office, 2013), but the Council of Europe (2010) suggest as many as $700,000-1,000,000$. In Hungary practically the Roma are the only visible minority, and have been present for centuries. Roma in Hungary are linguistically assimilated: practically all speak Hungarian, some only Hungarian, others are bilingual, and they also do not differ significantly from the majority in religious affiliation. Also, Roma in Hungary live a sedentary lifestyleunlike some Roma communities in Europe-; only a very small group of Sinti (estimated to be less than $1 \%$ among the Roma population, some operating travelling carnivals/carousels) are semi-sedentary (Szuhay, 2003).

The Hungarian Roma population is very diverse: there are three main groups (and several subgroups) of Roma in Hungary, in cultural and linguistic senses: the Romungros-who are linguistically assimilated, and speak Hungarian as a mother tongue-, the Boiashmany of whom speak a language which is based on an ancient version of Romanian-, and those who also 
speak different dialects of the Romani language (the most widespread version is the Lovari) (Kemény \& Janky, 2003). The Hungarian Roma community is extremely diverse and heterogeneous, unified only by the "othering" of the majority, and the political concept of the Roma, as constituted by state policies, and to a very limited degree, the international Romani movement (see e.g. Fosztó (2003)).

With respect to identity and advocacy, there are two competing ideologies and movements among Roma intellectuals in Hungary: one centered around civilrights-oriented emancipatory politics (Horváth, 2004), another with ethno-national cultural identity in focus. The former emphasizes antidiscrimination and desegregation, the latter groupism and cultural rights. András Bíró (2013) calls these groups modernists and culturalists: "Modernists are mostly drawn from a younger urban elite who see themselves as representatives of an ethnic minority group facing multiple social, economic, educational, but primarily, discrimination problems. Consequently their problems focus on equal opportunities, human rights and integration. Culturalists are located primarily in rural areas and while less visible, are a significant presence in Roma communities. Headed by an older leadership, these prefer retaining tradition to integration" (pp. 33-34).

A note on terminology: in line with the Council of Europe Descriptive Glossary of terms relating to Roma issues (2012), throughout the text I will use the term Roma, but it needs to be added that in Hungarian the term "cigány" and "roma" are used interchangeably. Before 2011 the minority rights act and most government documents used the former term, while politically correct analysts and advocates would prefer the latter. According to the aforementioned Glossary of the Council of Europe (2012), currently Council of Europe documents prefer the term "Roma", referring to "Roma, Sinti, Kale and related groups in Europe, including Travellers and the Eastern groups (Dom and Lom), and covers the wide diversity of the groups concerned.... The term 'Roma/Gypsies' was used for many years by before the decision was taken to no longer use it in official texts in 2005..., in particular at the request of International Roma associations who find it to be an alien term, linked with negative, paternalistic stereotypes which still pursue them in Europe. Consequently...it is recommended that the word 'Gypsy' or its equivalent no longer be used, as it is felt to be pejorative and insulting by most of the people concerned" (pp. 3-4). The term "cigány" is closely connected to "Gypsy", and the etymologically related "Zigauner", and "Gitano". Similarly to several parts of former Yugoslavia, in Hungary, depending on the context, it may actually not carry a stigma at all; some Hungarian communities only used this term for selfidentification and until very recently were unfamiliar with the term "Roma", and many even today selfidentify as "cigány", and prefer the term over "Roma".

\subsection{The Hungarian Minority Rights Framework}

The starting point to understanding the contemporary Hungarian minority rights framework dates back to 1920 , when in the post-WWI treaty ${ }^{21}$ Hungary lost twothirds of its territory and the corresponding population. Ever since, the aspirations to reunite and reinstate the old glory and territorial integrity (or at least a responsibility for ethnic kins in the neighboring countries) have always been a cornerstone of conservative domestic politics, and after the political transition in 1989 a constitutional responsibility and a foreign policy priority as well. Arguably, the 1993 Act on the Rights of National and Ethnic Minorities, ${ }^{22}$ was designed in a way to provide a politically marketable example for the neighboring countries with a substantial Hungarian minority (see e.g. Pap (2006) and Bíró (2013)). The law enumerates 13 recognized minorities: Armenian, Bulgarian, Croatian, German, Greek, Polish Romanian, Ruthenian, Serb, Slovak, Slovenian, Ukrainian, and Roma. There is a complicated procedure to extend the list, which involves a popular initiative, an advisory opinion of the Hungarian Academy of Sciences and a vote in the Parliament amending the Act, and no such initiatives were successful so far. The Act guarantees cultural and linguistic rights for these groups, and contains provisions on the establishment and maintenance of minority education and establishes a unique Hungarian institution, the minority self-governments (hereinafter MSGs). Funded by the local authorities or by the State where national bodies are concerned, MSGs operational in the local, regional and national level, have special competences for protecting cultural heritage and language use, fixing the calendar for festivals and celebrations, fostering the preservation of traditions, participating in public education, managing public theatres, libraries and science and arts institutions, awarding study grants and providing services for to the community (legal aid in particular). MSGs are thus elected bodies, functioning parallel to mainstream institutions, and have certain rights regarding decision-making in the areas of local education, language use in public institutions, media, and the protection of minority culture and traditions; minority selfgovernment representatives have the right to provide input on public policy matters through access to the local councils' committee meetings. In 2006, 1118 local Roma minority self-governments were operating in Hungary (NDI, 2007, p. 5); in 20101248 (Kállai, 2011a, p. 25), and in 20141197 Roma minority self-governments were elected (National Election Office, 2014). (National censuses, as well as elections of minority governments are all based on voluntary self-identification.)

\footnotetext{
21 Treaty of Peace Between the Allied and Associated Powers and Hungary and Protocol and Declaration. Signed at Trianon, June 41920.

${ }^{22}$ Act LXXVII of 1993.
} 
The law, thus set forth a broad set of cultural and political rights for traditional national minorities, and Roma ("cigány", as it stood in the law). It is worth noting that the name of the law included both national and ethnic minorities, with Ruthenians being the only group besides the Roma which does not have a nation state. (The Ruthenian community numbered 1098 in the 2001 census and 3882 in the 2011 one, with 1113 and 999 native speakers respectively (National Ruthenian Self-government (2013)).

Connecting to discussions in the first part of the paper, the function and the design of the MSGs is quite ambiguous: political representation and empowerment, cultural competences and a vague promise of social integration potential is bundled together. Generally, while acknowledging that it serves as a "training school" for up-and-coming Romani politicians, giving them skills that they can use in the mainstream political arena, observers are quite critical of the institutional design (Barany, 2002; Curejova, 2007; Kovats, 1996; Majtényi, 2005, 2007; Thornberry, 2001). As Melanie Ram notes (2014), the MSG-system, "which at times has been touted as a possible model for other countries, has not brought a substantial improvement in Roma lives. While it has increased participation of Roma to some extent, it has hardly enhanced social inclusion of Roma, largely because its mandate is limited to cultural autonomy (basic education, media, language, and promotion of culture. The language provisions are simply not so helpful for a community that largely speaks Hungarian at home, and local self-governments do nothing to directly address either discrimination or socioeconomic inequalities" (p. 31). According to the report of the National Democratic Institute (supported by the Democratic Institutions and Human Rights of the Organization for Security and Co-operation in Europe), "the MSGs tend to marginalize Romani issues by depositing them in a parallel, fairly powerless, quasigovernmental structure rather than addressing them through established governing bodies" (NDI, 2007, p. 6). Claude Cahn argued (2001) that the framework is not only "largely inappropriate for addressing the situation of Roma" but has "reified the exclusion of nonwhite minorities in Hungary". The above mentioned report of National Democratic Institution (NDI, 2007) pointed to many problems with the system. These included "unclear competencies, the lack of differentiation between various minority needs, deficiencies in financing, and voter enfranchisement regardless of ethnic affiliation" (p. 5). According to the report: "Hungary was among the first countries to create a system to promote minority rights and its minority selfgovernment offers a unique approach to fostering Romani participation. While some consider it a model for countries with significant Romani populations, many in the international community, and among Roma themselves, say that [it-ALP]...tinkered with a fun- damentally flawed concept that offers the illusion of political power rather than genuine inclusion ( $p$. 4)....The MSGs tend to marginalize Romani issues by depositing them in a parallel, fairly powerless, quasigovernmental structure rather than addressing them through established governing bodies....MSGs fall far short of the range of competencies that the title 'self government' implies. They lack the authority to take action outside of a very limited scope of issues and function more like NGOs than elected governing bodies. The use of the term 'self-government' is not merely inaccurate, but actually damages the credibility and legitimacy of the entire system among Roma, as it raises unrealistic expectations on the part of constituents regarding what they can accomplish through the MSGs. In truth, the very design of the system prevents it from having a significant impact on issues of greatest concern to most Roma and hinders political integration. This is due in part to the fact that these were not the government's initial aims in creating the system. Rather, its goal was to give minorities a safeguard for preserving their distinct cultural and linguistic traditions, and...to provide the means for encouraging neighboring countries to allow Hungarian minority communities the same privilege. Governance over socio-economic policy was never the intention" (p. 6). The NDI also points to flaws in funding, claiming that "MSGs lack adequate funding to carry out either socio-cultural projects, per the system's original intent, or additional projects to improve the living standards of community members. With a budget of approximately $\$ 3,000$ per year, with no consideration for the size of the town or Romani population, MSGs cannot cover even a modest stipend for a part-time employee to coordinate the work of its elected representatives or implement projects" (p. 6). "...Roma often approach their MSG expecting assistance related to a broad number of issues including housing, employment, discrimination and utility services. This problem is often exacerbated by many local governments which send Romani constituents to their minority self-government to seek help in areas where the MSG has no mandate. As a result, citizens often find no answer to their questions or requests and emerge from the process disillusioned with both their Romani and mainstream representatives. This lack of authority leaves MSGs as a 'half-way house' between a government institution and an NGO, with an undefined, under-funded mandate. Other than very limited government funding and the right to consent in issues of education, language, and cultural preservation, the MSGs have few advantages over NGOs....As consultative bodies, the MSGs have not proven to be effective in promoting Romani interests on a broad array of mainstream policy debates" (p. 24).

In sum, the NDI report pointed out that, "the government's stated purpose for creating the Minority Act was to assure the cultural autonomy of minorities and 
to fulfill international obligations regarding the protection of minority rights. However, another important factor in the development of the act was Hungary's desire to protect the rights of the large number of ethnic Hungarians living in neighboring countries. By developing the MSG system and other minority institutions, the government hoped to build leverage that it could use in bi-lateral negotiations with neighboring states on guaranteeing the rights of Hungarians abroad...the MSG system in Hungary is not specific to the Roma community and includes 12 additional minority groups....While other minorities are primarily concerned with protection of cultural and linguistic autonomy, the Roma population faces an almost opposite challenge, needing more integration to combat segregated education, discrimination, unemployment, and problems with housing and healthcare" (p. 5).

Hungarian Roma leaders repeatedly call for a redistribution, rather than recognition-oriented minority policy. ${ }^{23}$ According to Molnár and Schaft (2003), "Roma self-governments see as their main objective the improvement of social conditions in their community rather than the preservation of minority culture and strengthening of minority identity. The ambitions of local Roma leaders are influenced primarily by the marginalization of their community, while the protection of Roma identity remains secondary" (p. 41).

\subsection{Beyond Cultural Rights...}

Despite the fact that none of the targeted national minority communities ever voiced their demands in a politically compelling way (and Roma representatives certainly would not have advocated such a framework), the first freely elected Hungarian government acted in a proactive manner, exceeding international minority rights commitments and created an identity-politics oriented minority rights framework-even if partly, or mostly in order to fuel national sentiments and political commitments towards ethnic Hungarians in the Diaspora.

As Balázs Vizi points out (2013), despite all its flaws, for the first time in Hungarian history, the 1993 law formally recognized the Roma as a group with legitimate claims for a separate identity. Admittedly, the law facilitated a peculiar nation-building project (see for example Fosztó (2003)), conceptualizing a Roma national minority, a distinct political group, incorporating all its diverse subgroups. Also, the law to a certain degree successfully endorsed cultural aspirations of certain Roma communities and created a Roma political elite (Bíró, 2013), its declaration concerning the prohibition of discrimination, a daily practice for Roma in Hungary in all facets of life, received very little atten-

23 For an academic assessment of the "redistributionrecognition dilemma", which are conceptualized both as analytically distinct categories of justice, see Fraser (1995). tion. For example, the first comprehensive antidiscrimination law was adopted only in 2003, 10 years after the minority rights law, necessitated by EUaccession obligations, and in 2000, only three years before its adoption, the Constitutional Court rejected complaints pertaining to the lack of such a legislation. ${ }^{24}$ Likewise, the law was unfit to meet social inclusion demands in dire need for Roma communities. Despite the shocking sweep of market economy that hit the impoverished Roma the hardest, in the first decade or so after the political transition there were no serious attempts to institutionalize social inclusion measures targeting the Roma, as Hungarian legislators' priorities concerned enhancing exportable cultural identity for national minorities.

Let us now investigate further developments in these areas. What we will see is that the gradual progress we may acknowledge is also hardly a consequence of thoughtful concise strategizing, and that although European Union accession did fertilize and accelerate the development of social inclusion and anti-discriminatory measures, the conceptualization of these policies and envisioning the Roma in this process is just as blurry and inconsistent as in the inconsistent and internally contradictory multiculturalist model as set forth by the 1993 minority rights law.

\subsection{Accession and the Role of the European Union}

As analysts point out, in order to minimize unwanted mass migration after accession, the EU made efforts to facilitate the social inclusion of the marginalized Roma communities during the accession process (Guglielmo, 2004; Vermeersch, 2003; Vizi, 2005). However, as Balázs Vizi (2013) points out after a thorough analysis of accession reports, the European Commission was insensitive towards the difference between the complexity of social inclusion measures tailored to Roma and minority rights frameworks that enhance minority identity. There was no recognition or commitment to a separate assessment of assimilationist, integrational measures, and inclusion strategies that in fact build and rely on a separate and special ethno-cultural identity. Given the heterogeneity of Roma in Hungary and the very advanced degree of their assimilation, this was a severe omission. In a way, although doing the opposite, the European Commission turned out to be just as obtuse, blindfolded and conceptually disoriented as the Hungarian legislator. Even though annual accession progress reports and documents adopted by the European Parliament and the Commission discussed Romarelated issues under "minority rights" labels, recommendations and concerns only focused on antidiscrimination, very broad social integration measures and complaints against the treatment of Roma by the

${ }^{24}$ Decision No. 45/2000 (XII. 8.). 
police and other authorities-none actually having to do much with minority rights (Vermeersch, 2009). Even the question of the parliamentary representation of minorities was seen as a missing tool for social integration and not as that of political participation (Vizi, 2013). The preservation of cultural identity was never raised within accession progress reports.

Despite these ambiguities concerning the conceptual framework of EU-accession demands, analysts agree on the efficiency of the pressure it put on Hungarian policy-makers to facilitate Roma social inclusion, which certainly improved after 1997. (It needs to be added that some argue that it may also have been due to the fact that this was the time by when the inadequacy of the 1993 law became apparent to the governments.) Even though the first government resolution on Roma integration was adopted in $1995,{ }^{25} 1997$ marked a significant expansion in both the number of government documents, ${ }^{26}$ strategies, action plans, etc. adopted and the broadening of the perspectives within (Vizi, 2013). Recognizing its policies as successful, during the accession process, the EU granted Hungary the largest amount of support from the EU for Roma integration as part of the PHARE programme: 18 million Euros between 1999 and 2001, altogether 34.5 million between 1999 and 2006 (National Development Agency, 2008).

\subsection{From Ethnic to National Minorities: The New Hungarian Constitutional Order}

The new 2011 Hungarian Constitution and the subsequently adopted new Act on the Rights of Nationalities $^{27}$ (i.e. minorities) which officially replaced the term "cigány" with "roma", re-labeled Hungarian minorities to "nationalities" ("nemzetiség") from "national and ethnic minorities" ("nemzeti és etnikai kisebbségek"). There is no evidence (for example in parliamentary debates or government documents) that this shift in terminology would have been based on overarching theoretical or conceptual reasoning, or it would have been accompanied by systematic political commitments, or that it even was determined with the Roma in mind. It is not clear what the legislator's problem was with the previous definition of "national and ethnic minority". Presumably, the constitution-maker neither disputed that "nationalities" constitute a numerical minority within society, nor that they suffer from certain disadvantages (which the minority law is designed to redress by setting forth minority rights). Furthermore, putting aside the difficulty of differentiating between "national" and "ethnic" minorities, nothing supports the understanding (and even the Hungarian legislator failed

25 Government Resolution No. 1120/1995 (XII. 7.).

${ }^{26}$ Government Resolution No. 1093/1997 (VII. 29.); 1048/1999

(V. 5.); 1186/2002 (XI. 5.); 1021/2004 (III.18.).

${ }^{27}$ Act CLXXIX of 2011. to make this claim) that a "nationality" could or would be regarded as a greater set comprising both (Chronowski, in press; Magicz, 2013; Majtényi, 2014). Thus the most accurate description would be that it is synonymous with "national minority". It is no coincidence that the terminology used in international documents also employs the aforementioned distinctions, and that the original draft of the Fundamental Law talked of "nationalities and ethnic groups".

During the drafting of the new constitution in 2011, the Croatian ${ }^{28}$ and the Ruthenian ${ }^{29}$ national minority self-governments welcomed the change in terminology, which was also recommended by the minority rights ombudsman, because for some unexplained reason they considered the term "minority" demeaning. It is well to add that only four of the 13 NMSG's took the effort to comment on the draft constitution (all 13 were asked to do so as requested by the parliamentary committee in charge); crucially, the Roma minority selfgovernment remained silent.

The preamble of the new constitution proclaims that "the nationalities living with us form part of the Hungarian political community and are constituent parts of the State", and this is repeated in Article XXIX. Although it is a repetition of the previous constitution's provision (not a verbatim reiteration, but substantially the same), despite several Constitutional Court decisions seeking to interpret its meaning, it still remains ambiguous. It would not raise interpretational questions if minorities were held to be constituent elements of the nation, but the semantic connotations of minorities or nationalities that are constituent parts of the state is rather confusing outside a Bosnian-style ethnic federation. ${ }^{30}$ All in all, it appears therefore that members of the Hungarian nation, having given themselves a constitution, share public power with the nationalities that live with them. Incidentally, these nationalities are not subjects of the constitution, since the preamble of the Fundamental Law states that it is authored and framed by members of the Hungarian nation-even if there may have been (and in fact there were) members of parliament (even some governing party MPs who adopted the constitution) who are members of a national minority.

One significant development concerns the introduction of parliamentary representation for all nationalities as set forth by a new electoral law. For the most part, the 2011 nationalities act practically left the previous legislation intact, except for depriving minority self-governments of their veto rights concerning some local legislation. A rather curious development con-

\footnotetext{
28 AEB/139/2010, retrieved from www.parlament.hu/biz39/ aeb/info/horvat_onk.pdf

${ }^{29}$ AEB/136/2010, retrieved from www.parlament.hu/biz39/ aeb/info/ruszin_onk.pdf

30 Decisions no. 1041/G/1999; 35/1992 (VI. 10.); 24/1994 (VI. 6.).
} 
cerns Roma minority self-governments (but not other minority self-governments) as they have formally been involved in social inclusion measures, creating an even more confusingly hybrid, mutant model. As an annex to the first version of the Hungarian National Social Inclusion Strategy (2011), the government signed a framework agreement with the National Roma SelfGovernment, and competences including the supervision of schools, developing new employment schemes, monitoring programmes have been assigned to the NRSG. In fact, it has been appointed as one of the core implementing bodies of the Strategy (Annex 2).

The new legislation, backed up by constitutional language, clearly signals that on the one hand, the legislator as well as the right wing populist elite conceptualize Roma issues as foremost within identity politics. On the other hand, government rhetoric and initiatives use cultural identity as a tool for social integration, and presents it in a simplified, essentialist, manner. ${ }^{31}$ Let us see some examples from the first version of the Hungarian National Social Inclusion Strategy (2011), adopted in order to reflect policy aims set forth by the European Framework for National Roma Integration Strategies (which, following the "explicit but not exclusive targeting" principle targets several vulnerable groups ${ }^{32}$ ): "The fostering and popularisation of Roma culture...should not result in an effect contrary to the desired goal by overly emphasising the cultural 'differentness'....As the fostering of Roma culture contributes to the positive shaping of the social image of the Roma...we must...enable the majority society to acquaint themselves with the values of Roma traditions and culture in Hungary and abroad alike.....Learning about the life, values and culture of the other community is an effective means of the fight against stereotypes. We must therefore lay particular emphasis on providing information in public education on the culture and history of the Roma as a part of the multi-faceted Hungarian culture as well as on presenting the effects of the Roma culture on the national and Eastern European culture" (Chapter VI. Involvement, awareness raising, fight against discrimination, pp. 96-98). This approach is further articulated in the updated version of the integration plan (2014), which emphasizes the role of maintaining cultural traditions, which can function as a source of pride and confidence and "which is a prerequisite for the self-esteem, the consciousness-raising, and the re-creation of the integrity of Roma community". While the document sets forth the goal to "reshelve projects fostering Roma culture from social issues to cultural identity" it also calls for the integration of a social inclusion approach to Roma educational and cultural programs (Dinók, 2012).

31 See for example a speech delivered by the Minister of $\mathrm{Hu}-$ man Resources (MTI-EMMI, 2014).

${ }^{32}$ See Vizi (2011).
Flaws in the Strategy and its policy environment have been thoroughly criticized in the monitoring report commissioned by the Decade of Roma Inclusion Initiative ${ }^{33}$ and compiled by an NGO coalition ${ }^{34}$ involving most of the relevant organizations in Hungary (Balogh et al., 2013). For example, it points out that "some of the missing policies are closely connected with anti-discrimination and equal opportunities policies...abolishing the institution of the Parliamentary Commissioner for the Rights of National and Ethnic Minorities and moving this function to the portfolio of the deputy of the Commissioner for Fundamental Rights, have resulted in far less powerful institutional tools for combating discrimination. Hungarian authorities do little to sanction hate speech, and criminal law provisions designed to protect groups facing bias are more often applied by the authorities to sanction Roma rather than non-Roma. In case of most hate crimes, no proper criminal procedure is launched. Romani women and children suffer extreme forms of exclusion, too. At the local level, the powerless position of minority selfgovernments has been further weakened: their consent is not obligatory any longer to decide on matters affecting the local Romani community (while, on the other hand, numerous governmental tasks which go far beyond the legitimate political role of national minority self-governments have been assigned to the National Roma Self-Government" (pp. 9-10). Also, "the circumstance that public security measures are connected with the measures aimed at the Roma inclusion is quite problematic, since this gives the impression that ethnic origin is connected to criminality" (p. 37). The NGO coalition makes the following general recommendations: "...the human rights and fundamental rights based approach, including the principle of nondiscrimination, should be strengthened and become more dominant in the Strategy and its implementation....Concerning hate crimes committed against vulnerable groups (especially Roma), coordinated measures should be taken in the following areas: data collection, accessibility of court decisions, preparing an adequate investigation protocol, training and awareness raising of law-enforcement professionals, providing information to victim groups....Public policy measures should take into account the multiple disadvantages of Romani women and the phenomenon of intersectionality....The principle of social equality between men and women should also be applied as a horizontal aspect in Roma inclusion policies.... When planning public policy measures, it should be taken into account that human trafficking and prostitution are areas where inequalities based on gender, ethnicity and social status interconnect" (pp. 11-12).

33 For the assessment of the Decade see Kóczé and Mirescu (2011) and Jang (2015).

${ }^{34}$ For the role of NGOs see Kóczé (2012) 


\section{Conclusion}

The Hungarian case serves as a litmus test for showing that labeling does not necessarily involve form-fitted conceptualization, and that terminology does not necessarily determine policy instruments. In the Hungarian case, the confusing legal terminology reflects and reveals confused conceptualization and the lack of clearly defined political and policy objectives. Here, despite all the efforts of human rights NGOs in strategic litigation and policy recommendations (e.g. the European Roma Rights Center or the Chance for Children Foundation) the collectivist, essentialist and patronizing approach, and the relabeling of the Roma as a nationality, is accompanied by a neglect of the individual justice based, anti-discrimination oriented approach. This clears the path for far-right rhetoric centered on collective responsibility, culturally rooted, but in essence ethnicized criminality, or the parasitical "culture of poverty", and an unwillingness to adopt Hungarian middle class norms and lifestyle. In sum, the terminology used in official documents, the new constitution, laws and policy frameworks, fail to comprehend the complexity of Roma-related issues, and even the essential difference the various policy models (minority rights, antidiscrimination, social inclusion) carry and require. Ironically, anti-discrimination focused policies advocated by the European Commission were equally blindfolded and obtuse concerning the differentiated nature of these policies.

\section{Conflict of Interests}

The author declares no conflict of interests.

\section{References}

Balogh, L. (2012a). Jog a kultúra őrzésére-Vagy ürügy a szegregációra? A roma nemzetiségi oktatás mint kétélü kard Magyarországon [The right to protect culture-Or an excuse for segregation? Roma minority education, a double-edge sword in Hungary]. Pro Minoritate(Spring), 207-223.

Balogh, L. (2012b). Minority cultural rights or an excuse for segregation? Roma minority education in Hungary. In D. Pop (Ed.), Education policy and equal education opportunities (pp. 207-222). New York: Open Society Foundations.

Balogh, L., Berki, J., Daróczi, G., Farkas, Zs., Ivány, B.;Kóczé, A., Koltai, L., Kóródi, M., Kőszeghy, L., Moldova, Zs., Novoszádek, N., Somogyi, E., Szendrey, O., Teller, N., \& Wagner, J. (2013). Civil society report on the implementation of the national Roma integration strategy and decade action plan in Hungary in 2012. Budapest: Decade of Roma Inclusion Secretariat Foundation.

Barany, Z. (2002). The East European gypsies: Regime change, marginality and ethnopolitics. Cambridge: Cambridge University Press.

Bíró, A. (2013). The price of Roma integration. In W. Guy (Ed.), From victimhood to citizenship: The path of Roma integration. A debate (pp. 11-40). Budapest: Pakiv European Roma FundKossuth.

Bragyova, A. (1994). Are there any minority rights? Archiv für Rechts- und Sozialphilosophie, 90, 489-586.

Cahn, C. (2001). Smoke and mirrors: Roma and minority policy in Hungary. Roma Rights, 4.

Central Statistical Office. (2013). A népesség anyanyelv, nemzetiség és nemek szerint [The population by mother tongue, nationality and gender]. Országos adatok [National Data]. Retrieved from: www.ksh.hu/nepszamlalas/docs/tablak/teruleti/00 /1_1_6_1.xls

Chronowski, N. (in press). Alaptörvény és etnicitásAvagy az alkotmányozás viharaiban részekre szakadt nemzetünk [Fundamental law and ethnicity-Our nation torn int he storm of constitution-making]. Állam- és Jogtudomány, 56(1).

Council of Europe, \& ERICarts. (2015). Hungary. Compendium of cultural policies and trends in Europe (February 10). Retrieved from: http://www.culturalpolicies.net/web/hungary.php? aid $=424$

Council of Europe. (2010). Statistics. Retrieved from: www.coe.int/t/dg3/romatravellers/default_en.asp

Council of Europe. (2012, May 18). Descriptive glossary of terms relating to Roma issues. Retrieved from: http://a.cs.coe.int/team20/cahrom/documents/Glo ssary\%20Roma\%20EN\%20version\%2018\%20May\% 202012.pdf

Council of Europe. (1995). Framework convention for the protection of national minorities and explanatory report. Strasbourg: Council of Europe.

Council of Europe. (2000). Advisory committee on the framework convention for the protection of national minorities (2000). Opinion on Denmark, adopted on 22 September 2000, ACFC/INF/OP/I(2001)005. Strasbourg: Council of Europe.

Curejova, L. (2007, August 22). Self-abusive governance. Transitions Online. Retrieved from http://www.tol.org/client/article/18943-selfabusive-governance.html

Dinók, H. (2012). Stratégia vs. oktatásügy [Strategy vs. education politics]. Fundamentum, 1, 63-66.

European Commission. (2010). The 10 common basic principles on Roma inclusion: Vademecum. Luxembourg: EU.

Feischmidt, M. (2014). A mindennapi nacionalizmus és a másság cigányként való megjelölése [Banal nationalism and signifying the other as Roma]. In M. Feischmidt (Ed.), Nemzet a mindennapokban. Az újnacionalizmus populáris kultúrája [Banal nation: 
The popular culture of neo-nationalism] (pp. 401447). Budapest: L'Harmattan - MTA TK.

Fosztó, L. (2003). Diaspora and nationalism: An anthropological approach to the international Romani movement. Regio: Minorities, Politics, Society, 1.

Fraser, N. (1995). From redistribution to recognition? Dilemmas of justice in a "post-socialist" age from redistribution to recognition? New Left Review, 212(July-August), 68-93.

Guglielmo, R. (2004). Human rights in the accession process: Roma and Muslims in an enlarging EU. In G. N. Toggenburg (Ed.), Minority protection and the enlarged European Union: The way forward. Budapest: OSI-EURAC.

Hannum, H. (2001). International law. In A. Motyl (Ed.), Encyclopedia of nationalism (pp. 405-419). San Diego and London: Academic Press.

Havas, G., Kemény, I., \& Kertesi, G. (1998). A relatív cigány a klasszifikációs küzdőtéren. Kritika, 3, 193201.

Horváth, A. (2004, July 12). Magyar nemzet, roma nemzet. Népszabadság, p. 6.

Human Rights Commission. (2004). Travellers as an ethnic minority under the convention on the elimination of racial discrimination: $A$ discussion paper (24th March ed.). Dublin: Human Rights Commission.

Hungarian National Social Inclusion Strategy. (2011). Extreme poverty, child poverty, the Roma 20112020. Budapest: Ministry of Public Administration and Justice.

Hungarian National Social Inclusion Strategy II. (2014). The permanently needy: Children living in poor families-The Roma; 2011-2020. Updated version. Budapest: Ministry of Human Resources.

Jang, M. (2015, February 11). A Roma education. Harvard Political Review. Retrieved from http://harvardpolitics.com/world/roma-education

Kállai, E. (2011a). Beszámoló a Nemzeti és Etnikai Kisebbségi Jogok Országgyülési Biztosának tevékenységéröl, 2010 [Report on the activities of the Parliamentary Commissioner for the Rights of National and Ethnic Minorities, 2010]. Budapest: $\mathrm{OBH}$.

Kállai, E. (2011b). Jelentés a nemzeti és etnikai kisebbségi általános iskolai nevelés-oktatás helyzetéröl [Report on the situation of national and ethnic minority education in elementary schools]. Budapest: $\mathrm{OBH}$.

Kállai, E. (2011c). Jelentés a nemzeti és etnikai kisebbségi óvodai nevelés helyzetéröl [Report on the situation of national and ethnic minority education in kindergartens]. Budapest: $\mathrm{OBH}$.

Kállai, E. (2014). Vannak-e cigányok, és ha nincsenek, akkor kik azok? [Are there any Roma and if not, who they are?]. Regio, 22(2), 114-146.
Kaufman, E. P. (2014). Immigration and Integration in Britain: the great nationalism debate. Nationalities Papers, 42(6), 1072-1077.

Kemény, I., \& Janky, B. (2003). A 2003. évi cigány felmérésről: Népesedési, nyelvhasználati és nemzetiségi adatok [About the Gypsy survey in 2003: Data on demographics, spoken languages and nationality]. In E. Kállai (Ed.), A magyarországi cigány népesség helyzete a 21 század elején [The situation of the Gypsy population in Hungary at the beginning of the 21 century] (pp. 7-26). Budapest: MTA Etnikai-nemzeti Kisebbségkutató Intézet.

Kóczé, A. (2012). Civil society, civil involvement and social inclusion of the Roma. Bratislava: United Nations Development Programme.

Kóczé, A., \& Mirescu, G. (2011). A look behind the curtain: Reflections on the decade of roma inclusion. In G. Mirescu (Ed.), Social Inclusion and Cultural Identity of Roma Communities in South Eastern Europe (2011 ed., pp. 35-40). Bern: Swisspeace.

Kovats, M. (1996). The Roma and minority self-governments in Hungary. Immigrants \& Minorities, 15(1), 42-58.

Kymlicka, W. (2001). A Western political theory and ethnic relations in Eastern Europe. In W. Kymlicka \& M. Opalski (Eds.), Can liberal pluralism be exported? Western political theory and ethnic relations in Eastern Europe (pp. 13-107). New York: Oxford University Press.

Kymlicka, W. (2007). Multicultural odysseys: Navigating the new international politics of diversity. Oxford: Oxford University Press.

Ladányi, J. (2000). The Hungarian neoliberal state, ethnic classification and the creation of a Roma underclass. In R. J. Emigh \& I. Szelényi (Eds.), Poverty, ethnicity, and gender in Eastern Europe during the market transition (pp. 67-82). Westport: Greenwood.

Ladányi, J., \& Szelényi, I. (1998). Az etnikai besorolás objektivitásáról [On the objectivity of ethnic classification]. Kritika, 3, 33-35.

Ladányi, J., \& Szelényi, I. (2000). Adalékok a csenyétei cigányság történetéhez. Budapest: ATA - Új Mandátum.

Ladányi, J., \& Szelényi, I. (2001). Van-e értelme az underclass kategória használatának? [Does it make sense to use the category of underclass?] Beszélő, 6(11), 94-98.

Lewis, O. (1968). The culture of poverty. In D. P. Moynihan (Ed.), On understanding poverty (pp. 187200). New York: Basic Books.

Magicz, A. (2013). Re-regulation of national minority rights. In B. Hajas \& M. Szabó (Eds.), Their shield is the law: The Ombudsman's protection for vulnerable groups (pp. 27-30). Budapest: Office of the Commissioner for Fundamental Rights. 
Majtényi, B. (2005). What has happened to our model child? The creation and evolution of the Hungarian Minority Act. European yearbook of minority issues, 5(1), 397-469. doi:10.1163/22116117-90000055

Majtényi, B. (2007). A nemzetállam új ruhája [The nation state's new clothes]. Budapest: Gondolat.

Majtényi, B. (2014). Alaptörvény a nemzet akaratából [Fundamental law out of the will of the nation]. Állam- és Jogtudomány, 55(1), 77-96.

Majtényi, B., \& Majtényi, G. (2012). Cigánykérdés Magyarországon 1945-2010 [Gypsy question in Hungary, 1945-2010]. Budapest: Libri.

McCrudden, C. (2005). Thinking about the discrimination directives. European AntiDiscrimination Law Review, 1(18), 17-23.

McVeigh, R. (2007). "Ethnicity denial" and racism: The case of the government of Ireland against Irish travellers. Translocations, 2(1), 90-123.

Molnár, E., \& Schaft, K. A. (2003). Preserving "cultural authonomy" or confronting social crisis? Review of Sociology of the Hungarian Sociological Association, 9(1), 27-42.

MTI-EMMI. (2014). Balog Zoltán: A kultúrára kell építeni a felzárkóztatást. Retrieved from http://romagov.kormany.hu/balog-zoltan-akulturara-kell-epiteni-a-felzarkoztatast

National Democratic Institute for International Affairs (NDI). (2007). The Hungarian minority selfgovernment system as a means of increasing romani political participation: National Democratic Institute assessment report September/October 2006. Washington, DC: NDI.

National Development Agency. (2008). Ex-post evaluation of Roma programmes in Hungary financed by PHARE. Budapest: Hungary.

National Election Office. (2014, November 18). Önkormányzati választások, 2014. október 12.: Tájékoztató adatok a nemzetiségek települési önkormányzatainak választásáról [Municipal Elections, October 12, 2014: Local self-governments of nationalities, overview of the election results]. Retrieved from: http://valasztas.hu/hu/nemz2014/987/987_0_inde x.html

National Ruthenian Self-government. (2013, September 30). Népszámlálás 2011 [Population census 2011]. Retrieved from: http://www.rusyn.hu/hu/orszagos-ruszinoenkormanyzat/nepszamlalas-2011

Pap, A. L. (2006). Minority rights and diaspora claims: Collision, interdependence and loss of orientation. In O. leda \& B. Majtényi (Eds.), Beyond sovereignty: From status law to transnational citizenship? (pp. 243-254). Sapporo: Hokkaido University Slavic Research Center.

Pap, A. L. (2015). Is there a legal right to free choice of ethno-racial identity? Legal and political difficulties in defining minority communities and membership boundaries. Columbia Human Rights Law Review, 46(2), 153-232.

Permanent Court of International Justice. (1930). The Greco-Bulgarian “Communities" Series B. - No.17.

Ram, M. H. (2014). Europeanized hypocrisy: Roma inclusion and exclusion in Central and Eastern Europe. Journal on Ethnopolitics and Minority Issues in Europe, 13(3), 15-44.

Sajó, A. (1993). Protecting nation states and national minorities: A modest case for nationalism in Eastern Europe. University of Chicago Law School Roundtable (Special Issue), 53-74.

Simon, P. (2007). "Ethnic" statistics and data protection in the Council of Europe countries: Study report. Strasbourg: Council of Europe.

Stewart, M. (2000). Spectres of underclass. In R. J. Emigh \& I. Szelényi (Eds.), Poverty, ethnicity, and gender in Eastern Europe during the market transition (pp. 191-204). Westport CT/London: Praeger.

Stewart, M. (2001). Depriváció, romák és 'underclass' [Deprivation, the Roma and 'underclass']. Beszélö, 6(7-8), 82-94.

Szalai, J. (2003). Conflicting struggles for recognition: Clashing interests of gender and ethnicity in contemporary Hungary. In B. Hobson (Ed.), Recognition struggles and social movements. Contested identities, agency and power (pp. 188215). Cambridge: Cambridge University Press.

Szalayné Sándor, E., \& Székely, L. (2014). Az alapvető jogok biztosa és a Magyarországon élő nemzetiségek jogainak védelmét ellátó biztoshelyettes jelentése az AJB-3894/2012. számú ügyben, a nemzetiségi középiskolai oktatás helyzetéröl [Report of the Parliamentary Commissioner for Fundamental Rights and of the Deputy Commissioner for the Protection of the Rights of Nationalities Living in Hungary on case no. $A J B-3894 / 2012$, regarding the situation of the secondary education of nationalities]. Budapest: AJBH.

Szuhay, P. (2003). "Ez egy eredeti cigányélet" ("This is an original Gypsy way of life"), Beszélö, 8(5), 90-99.

Tajfel, H. (1981). Human groups and social categories: Studies in social psychology. Cambridge: Cambridge University Press.

Thornberry, P. (2001). An unfinished story of minority rights. In A.-M. Bíró \& P. Kovács (Eds.), Diversity in action: Local public management of multi-ethnic communities in Central and Eastern Europe (pp. 4673). Budapest: Local Government and Public Service Reform Initiative, Open Society Institute.

Vermeersch, P. (2003). EU enlargement and minority rights policies in Central Europe: Explaining policy shifts in the Czech Republic, Hungary and Poland. Journal on Ethnopolitics and Minority Issues in 
Europe, 1, 1-32.

Vermeersch, P. (2009). The Roma. In B. Rechel (Ed.), Minority rights in Central and Eastern Europe (pp. 61-74). London: Routledge.

Vizi, B. (2005). The EU and the situation of Roma in Hungary in the accession process. Central European Political Science Review, 6(20), 66-91.

Vizi, B. (2011). The Hungarian presidency of the Council of the European Union: Focus on the neighbourhood and on a European Roma strategy. Journal on Ethnopolitics and Minority Issues in Europe, 1, 123-134.

Vizi, B. (2013). Európai kaleidoszkóp: Az Európai Unió és a kisebbségek. Budapest: L'Harmattan.

Young, I. M. (1997). A multicultural continuum: A critique of Will Kymlicka's ethnic-nation dichotomy. Constellations, 4(1), 48-53.

\section{About the Author}

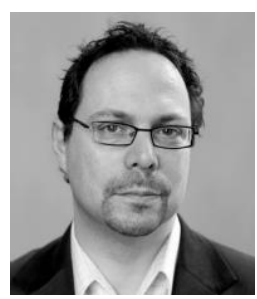

\section{Dr. András L. Pap}

András L. Pap is Research Chair and Head of Department for the Study of Constitutionalism and the Rule of Law at the Hungarian Academy of Sciences Centre for Social Sciences Institute for Legal Studies. He is an Associate Professor at Eötvös University (ELTE) Faculty of Humanities, Institute of Philosophy. He is also a member of the Law Enforcement Faculty of the National Public Administration University and a Recurrent Visiting Professor at Central European University's Nationalism Studies Program in Hungary. 